\title{
Dr P G Bakker
}

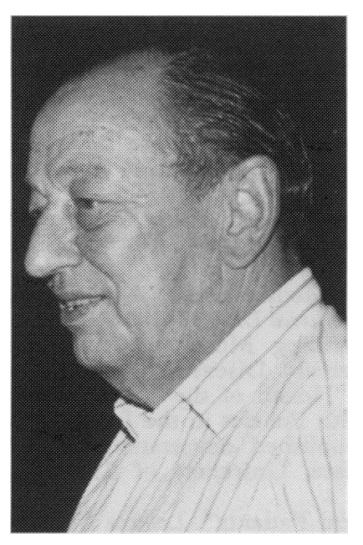

Dr P G Bakker, the well known and well liked Dutch dermato-venereologist died on 15 June 1993 at the age of 68 years.

Peter was the son of a dermatovenereologist and followed his father in the family practice. As a teenager he suffered under the Nazi occupation of Holland. Indeed he was made a prisoner for his activities in the underground. He was placed in a concentration camp in Holland in solitary confinement and was under sentence of death. His father happened to be treating a senior German officer for syphilis and was able to intercede that his son be spared. Peter was the only one of his group who was not shot.

After the second World War Peter studied medicine specialising in dermatology under the celebrated Professor Hermans at Rotterdam and soon taking over his father's thriving practice in The Hague. Peter Bakker with his colleague Theo Moolhuysen from Rotterdam were the two well known Dutch dermato-venereologists whose association with the Medical Society for the Study of Veneral Diseases goes back for over thirty years. His interest in sexually transmitted diseases within the United Kingdom was encouraged by $\mathrm{Mr}$ Ambrose King. Many will remember his role in the Spring Meeting of the MSSVD at Amsterdam in 1965. Pete居 was made an honorary life member of the MSSVD in 1985.

In his own country Peter was we recognised for his constant good advice an sensible opinions. He served on many loca Dutch organisations to do with dermatology$\mathrm{He}$ represented Holland in the Dermato venereology Committee of the European Union of Medical Specialists and became the Treasurer of that group. He was a founde member of the European Academy of the Dermato-venereology.

Peter Bakker had played an active role in the International Union Against the Venereas Diseases and the Treponematoses for very many years and had been a member of it Executive Committee for at least twentit years, becoming the Assistant Secretary General and later not only holding that pose but also becoming the Treasurer of IUVDT.

He was looking forward to retirement and was in his last month of practice wher he died. Venereology is lessened by the death of this good man, a constant frien and counsellor to us all. Our deepese sympathy goes to his family and to his children.
MA WAUGE曆 Secretary General, IUVDT 